\title{
Multicultural Education as Community Engagement: Policies and Planning in a Transnational Era
}

\author{
Kathryn A. Davis \\ Prem Phyak \\ Thuy Thi Ngoc Bui \\ University of Hawai i at Mānoa \\ U. S. A.
}

Through viewing multicultural education as policy and planning that is enacted at national, regional, and local levels in Nepal and Vietnam, we explore the challenges and possibilities of engaging communities. We examine transnationalism, neoliberalism, and globalization as these impact national policies, community ideologies, regional/local economy, social welfare, and education. Critical ethnographic studies further focus on history, place, and culture in engaging communities of policy makers, educators, students, families and activists in reflection and transformation, policy making, and planning. These studies serve to re-envision multicultural education as critical community engagement and transformation within a transnational era.

Transnationalism, Neoliberalism, and Education Resisting Monoculturalism in Nepal Reimagining Globalization, Multiculturalism and Education in Vietnam Multicultural Education as Community Engagement

Notes

References

Indigenous and multicultural education across borders reveals ongoing debate over policies affecting achievement among students from linguistically-diverse and socioeconomically-marginal communities (Davis, 2009; Luke, 2008, 2011). Researchers (Evans \& Hornberger, 2005; Luke, 2011; Wiley \& Wright, 2004) document the negative impact on students of global trends towards one-size-fits-all approaches to basic skills, textbooks, and standardized assessment. These and other scholars from multilingual countries such as Australia, Canada, Namibia, New Zealand, and the Republic of South Africa (Beukes, 2009; Luke, 2011) have argued for policies of inclusion which promote community ideologies and language choice in schools through culturally responsive and linguistically responsible education. Yet diversity research and community inclusion does not necessarily achieve intended transformation of material conditions and equitable social pathways for poor and marginal students. While language and literacy scholarship (Graff, 1979; Lo Bianco, 2010) reveals the limitations of schooling alone to redress social and economic inequalities, models are needed of community engagement in exploring global ideologies and local possibilities 
for social, economic, and educational transformation. Working towards local engagement necessarily involves mapping the complex intersection of transnationalism, neoliberalism, and globalization as these impact national policies, community ideologies, and regional/local economy, social welfare, and education. Engaging communities further suggests not only exploring the margins of current or previously privileged nations, but also geographic regions that are themselves marginalized within the global economic and social market place. Also assumed is a focus on the primacy of history, place, and culture when engaging communities in reflection and transformation, policy making, and planning (Luke, 2011).

This paper explores multicultural education as social transformation through engaged ethnographic studies in Vietnam and Nepal. Davis contextualizes these studies in theoretical and research perspectives on transnationalism, neoliberalism, and engaged community research and transformation. Phyak and Bui then document how global ideologies, national policies, and local histories and cultures impact and interact with situated policy-making and planning. Phyak's ethnography portrays far-reaching engagement with government officials, educators, communities, and youth in critical reflection on language policies, schooling, and human welfare in his home country of Nepal. Bui's ethnography of her own highly diverse community in the mountainous region of Vietnam engages students and teachers in critical reflection on schooling while seeking transformative spaces both in and out of classrooms. Together, we seek to conceptualize and theorize multicultural education as both profound connection with community and strategic use of global resources to address social and economic inequalities (Bourdieu, 1991, 1998; Freire, 1970). We begin with an overview of theoretical perspectives on transnational, neoliberalism, and education.

\section{Transnationalism, Neoliberalism, and Education}

Appadurai (2001) presents a compelling image of living "in a world of flows (of)...ideas and ideologies, people and goods, images and messages, technologies and techniques" (p. 5). This theory of flows re-envisions the notion of landscapes as encompassing ethnoscapes, languascapes, mediascapes, technoscapes, financescapes and ideoscapes that "are not objectively given relations that look the same from every angle of vision but, rather, deeply perspectival constructs, inflected by the historical, linguistic, and political situatedness of different sorts of actors" (Appadurai, 1996, p. 33). Considering the meanings of diversity from the perspective of flows and multiscapes more specifically argues for examining the global and situated nature of language, identity, and culture. Block (2006) argues that individuals often display membership of multiple groups depending not only on ethnicity, language group and nationality, but also on their personal beliefs and agency about the languages they speak and the socio-political and economic currency of those languages. Anthias (2001) suggests that individuals develop hybrid cultural identities through ongoing 'crossing of cultural and social borders' (p. 622). Holland and Lachicotte (2007) further hold that identity is not simply an endowed entity; rather it is a co-constructed phenomenon which occurs through constant interactions of individuals with their sociocultural contexts. 
Thus, in multicultural societies, individuals and collectives construct multiple identities, positionality, and agency by constantly negotiating their roles in time and space.

Yet transnationalism in conjunction with global neoliberalism also potentially has adverse effects on identity flows both through standardization in education and English language spread. Transnational language and culture theorists such as Tsui and Tollefson (2007) and Luke (2011) argue that language/culture loss and substandard education often occur under rhetoric of so-called quality education, social justice, and national development. A negative exemplar is the US-led transnational educational trend towards English dominant policies and standardized curriculum and testing. The stated purpose of the comprehensive 2002 No Child Left Behind (NCLB) initiative was "to ensure that all children have a fair, equal, and significant opportunity to attain a highquality education and reach, at a minimum, proficiency on challenging state academic achievement standards and state academic assessments" (NCLB, 2002). Just two years later the Harvard Civil Rights Project (Orfield, Losen, Wald, \& Swanson, 2004) reported nation-wide student outcome data indicating a "national crisis" in graduation rates of linguistic, ethnic, and racial minority students, especially in those states with the worst overall records of student graduation. Luke (2011) reports equally negative standardizing trends and achievement outcomes in countries such as Australia, New Zealand, and the United Kingdom. Lather (2004) notes that the "disciplining and normalizing effort to standardize educational research in the name of quality and effectiveness" (p. 26) shows, as Hall (1996) noted, an "aggressive resistance to difference (and) an assault, direct and indirect, on multiculturalism" (p. 468). Tsui and Tollefson (2007) further point out a concerning trend towards global expansion of English without critical understanding of local sociocultural complexities that can result in cultures and knowledge being disregarded and lost. These and other researchers (e.g. Luke, 2008, 2011; Widin, 2010) additionally report highly negative outcomes, in both English language development and threats to local languages and cultures, from neoliberal trends toward commodification of English language education through programs and products distributed or implemented in developing nations. While observing that high-quality and high-equity systems of education such as those of Finland and Canada do not follow the standardization/marketization model, Luke (2011) also emphasizes that these systems focus on local community and school-level curriculum interpretation and planning while sustaining support for child care, health care, and a social welfare infrastructure.

In recognizing the inescapable impact of transnational flows, we seek to explore the historical, linguistic, and political situatedness of complex identity formation and human welfare that go beyond Western or neoliberal models of economic and educational development. More specifically, we view engaging communities as critical endeavors initiated by those with historical, familial, and social ties with locally and/or ideologically marginalized peoples and institutions. While drawing on ethnography that is critical and involves Freirian consciousness-raising, we view engaging communities as centering on collective information-gathering and equity efforts among youth, teachers, and communities (Appadurai, 2006; Davis, 2009; Gegeo \& Watson-Gegeo, 2002). This approach moves towards personalizing and politicizing ethnography rather than removing actors, including researchers, from the centrality of action as is usual in critical ethnographic reports. It suggests a form of participatory action research that, 
rather than being site-, time-, and/or issue-specific, engages communities in interrogating and transforming the range of economic, social, political, and educational challenges they experience through time and space. While developing awareness of the sociopolitical meanings of local conditions, engaged communities across age, gender, social position, and institutional affiliation take ownership of plans for individual and/or collective action. In acknowledging that social activism and change is not always possible, engagement seeks "spaces" (Bhabha, 1983; Davis, 2009) for realizing personal and collective agency. The following ethnographic portrayals of multicultural education as community engagement in Nepal and Vietnam are intended not only to translate theory into practice, but also to uncover how critical dialogue and social practices can inform theory.

\section{Resisting Monoculturalism in Nepal: Possibilities and Challenges}

Although Nepal is a multicultural, multilingual, and multiethnic country ${ }^{1}$, it has a long history of monolingual and monocultural policies. Since the formation of the greater Nepal in 1768, an ideology of one-language (Nepali) and one-culture (Hinduism) has dominated governance and promoted hegemonic practices. The country's first legal code, the Muluki Ain-1845, classified society as five hierarchies in terms of the Hindu world order of relative purity (Gurung, 2006; Hangen, 2010). Accordingly, the high caste Tagadharis (wearers of the Holy Cord) were at the top of the hierarchy followed by the Matawalis (literally alcohol consumers) who were allotted non-enslavable or enslavable status. At the bottom of the hierarchy were both pure and impure untouchables (lowcaste Hindu) and religious minorities (e.g., Muslims and Christians). This hierarchical Muluki Ain provided the foundation for cultural hegemony through social injustice, humiliation, alienation, and shame for all castes other than the Tagadharis. The languages and cultural practices of the Matawalis, who are now recognized as Janajatis (indigenous nationalities and ethnic groups), were banned in schools. Following this legacy of oppression, the partyless Panchayat System (1960-1990), under the leadership of the then-King Mahendra, continued the same "one-language, one-nation and one-culture" ideology, but in the guise of modernization, nationalism and unity ${ }^{2}$. Although not officially granted the right to speak against this discriminatory monocultural ideology, ethnic groups including Newar, Tharu, Magar, Gurung, and Tamang formed their own underground associations ${ }^{3}$ to resist hegemonic linguistic and cultural practices. It was only after 1990, with the emergence of democracy, that the constitution recognized Nepal's identity as a multilingual, multicultural and multiethnic country. The newly formed nation-state granted people the right to preserve their languages, scripts, and cultures. Consequently, different ethnic groups formed their own organizations leading to the establishment of the Nepal Federation of Indigenous Nationalities (Adibashi Janajati Mahasangha) which has been actively working for the preservation and promotion of language, literature, script, religion, culture, and education among 56 identified indigenous nationalities ${ }^{4}$. Furthermore, the Federation is organizing and leading various movements towards engaging indigenous people in ensuring their linguistic and cultural rights, and in reclaiming their lost cultural, linguistic, territorial, religious, and social identities. The 2006-People's Movement (Janaandolan-II) officially 
put an end to the long history of monarchy and paved the way for declaring the Federal Democratic Republic of Nepal. Since then, the issue of recognizing diversity, as raised by marginalized ethnic groups and indigenous nationalities, has become a key political issue.

The following description of multicultural/multilingual possibilities is based on Phyak's engaged ethnography conducted in Nepal from May to August, $2012^{5}$. Phyak engaged community members, policy makers, indigenous activists and youth, and teachers in critical dialogue while he also, as an indigenous Limbu person, engaged in social movements and awareness raising programs about language, culture, identity, human rights, and social inclusion.

\section{Multicultural/Multilingual Possibilities}

Resisting the "internal colonization" of Hinduization and Nepalization (Allen, 1997; Pfaff-Czarnecka, 1997), the Interim Constitution-2007 declared Nepal a secular, multilingual, and multicultural state. Thus, indigenous communities were provided a legal space for reclaiming their cultural identities in education and other domains of society. The constitution has stated that receiving a basic education in one's mother tongue is a fundamental right. Subsequently, the Ministry of Education (MOE) in its 2007 National Curriculum Framework for School Education (henceforth National Curriculum) stated the need for acknowledging local knowledge, cultures, and languages in schools. The introduction of the National Curriculum states: "In the context of $21^{\text {st }}$ century human rights, child rights, peace, gender and social equity, population education and environment conservation, including global information and communication technology, have become the emerging needs" $(p .6)^{6}$. On the role of education in social transformation, the MOE further states:

Rights to quality education for all can only be ensured if education is taken as the major tool for social transformation and economic, cultural and political advancement. To be more precise, today's indispensable needs involve bringing reforms in access, equality, relevancy and quality in order to promote lifelong education. (p. 6)

In order to realize multiculturalism and multilingualism in education, the National Curriculum also adopted Local Needs Based Education. This policy states that utmost emphasis be given to the inclusion of local cultural practices, religions, and histories while designing curricula and textbooks for such education. The National Curriculum further draws on bilingual research in articulating the importance of mother tongue instruction in basic education. While this policy was designed for all Nepali-speaking students irrespective of their language backgrounds, a Multilingual Education (MLE) policy was initiated by the MOE in 2006 for non-Nepali speaking children from minority ethnic and indigenous communities. Aimed at increasing access and providing quality education, the MOE declared their support of indigenous approaches to teaching, learning, and developing curricula and textbooks (Nurmela, Awasthi, \& SkutnabbKangas, 2011; Smith, 2012). The MOE plan involves teaching all subjects (except 
Nepali and English) in the students' mother tongue up to Grade 3 with a gradual transition to Nepali. The MOE plan further states that multilingual education should be based on local indigenous knowledge, cultures, ecosystems, lifestyles, histories, and stories that are documented by local people and taught in local languages by local teachers (Nurmela Awasthi, \& Skutnabb-Kangas 2011). This participatory approach is intended to ensure engagement of ethnic groups at both the local and national level. The MLE also clearly stated its intent to promote indigenous community agency through support of locally developed school programs that provide relevant and effective learning. An indigenous activist and teacher who played a key role in the implementation of MLE in one of the rural villages suggested the importance of this MOE policy:

We had demanded for this [education in our own languages] for many years .... We had to teach children only in Nepali [in the past]. They [non-Nepali speaking children] could not understand it. Now the government has developed [MLE] policy, which is good. Our children [in this school] are learning easily these days. They can communicate [without hesitation] with their friends and teachers in schools. Children-friendly atmosphere has been created due to use of local languages and cultures in schools [the transcripts of excerpts in interviewees' original languages are provided in the Notes] ${ }^{7}$.

Highlighting the process of developing teaching and learning materials, this activist teacher further said:

Indigenous elderly people who know about local history, culture, herbal medicine, story, and art share their stories ... Such stories are recorded and used for developing textbooks for children. Community members are actively involved in selecting the content of the textbook ${ }^{8}$.

As argued by Hough, Thapa-Magar, and Yonjan-Tamang (2009), these actions are part of the community consciousness-raising process of discovering "how deep collective knowledge and talent really is" (p. 167). Thus, the MLE potentially adopts "critical indigenous pedagogy...which is grounded in indigenous epistemologies, metaphysics and values" (Hough et al., 2009, p.166). In an official discussion in Kathmandu, a bureaucrat from the Ministry of Education claimed that MLE has helped minority children "learn better in their home languages and created a multicultural atmosphere by teaching local cultures ${ }^{9}$."

Yet, while there have been policies and official rhetoric supporting multilingualism and multiculturalism, the reality on the ground has proven quite different. The following section explores the substantial challenges and increasing activist engagement in implementing multicultural/multilingual education.

\section{Multicultural/Multilingual Challenges}

Phyak's engaged ethnography reveals that a number of intersecting local and transnational forces are working against maintaining multicultural/multilingual policies in Nepal ${ }^{10}$. Most importantly, transnational and neoliberal influences are impacting the 
forms and outcomes of the MLE policy implementation. Since opening Nepal's borders to foreigners in the early 1950s (Whelpton, 2005) and adopting neoliberal ideologies in development planning since 1990, tourism, multinational companies, and the private sector have played active roles in the national economy. As the government promotes the mantra of public-private-partnership (PPP), the country has increasingly experienced private investment in business, education, hydroelectricity, real estate, and industry. Although the private sector contributes to national economic development to some extent, the widening gap between rich and poor, rural and urban in terms of access to economic, educational, and political opportunities is growing at an alarming rate.

Socioeconomic disparity is also considerably affected by dependency on support from donors for its development agendas. There is now a significant presence in Nepal of international agencies such as the World Bank, Asian Development Bank, European Union, USAID, AUSAID, and the Japan International Cooperation Agency. Both the World Bank and UNESCO have financially supported Nepalese education for the past 35 years. While UNESCO's official position is to value inclusive education and literacy in local languages, the World Bank promotes capacity building of schools and community participation through decentralization of education. The Nepalese parliament's Seventh Amendment of the Education Act in 2001 paved the way for community management of public schools. In 2003, the MOE launched the World Banksupported Community School Support Project that transferred management of public schools to communities with ambitious goals for increasing participation and improving the quality of public schools at the local level. Recent MOE statistics show that more than 7,000 schools, both private and public, have been transferred to communities.

The World Bank-supported School Management Communities (SMCs) are officially given rights to hire teachers, evaluate and monitor teaching-learning activities, raise and allocate budget, and make decisions related to management of schools. In reality, although this policy seems to promote decentralized education, it has not as yet brought positive changes towards quality education. Studies of the SMCs (e.g., Carney, 2009; Khanal, 2010) show that they are dominated by a very few people who have access to political institutions, while the community/parents' role has been to sanction these representatives' decisions. Due to this political intervention, schools are not able to appoint qualified teachers; rather, they have to employ those recommended by political parties. A critical issue arising from SMCs is that they are increasingly neither using indigenous languages nor Nepali, but only English as the medium of instruction. Community sources indicate that MOE personnel working in districts are also encouraging them in this direction. While these actions clearly challenge multicultural/multilingual policies, they also ignore the lack of teachers and resources for instituting English language education. Thus, children living in poor, rural, indigenous, and/or minority communities are most likely receiving little or no education.

Movement away from diversity education may both contribute to and be a perceived defense against poor education. One indication of these dual purposes is the rapid increase in the number of private schools. Initially opened for the urban privileged, these essentially-English medium of instruction schools also now serve a rising middle class (Eagle, 2008; Giri, 2010). They further do not comply with MOE 
policies. For example, although the National Curriculum (2007) and Curriculum Development Center (2008) have mentioned that either "Local Subject"11 or the "mother tongue" should be taught as one of the subjects at the primary level, all private schools (with some exceptions in Kathmandu and Ilam) have not introduced either of these subjects. As a consequence, local customs, languages, histories, religion, ethnicity, and geography are ignored and essentially create an implicit policy (Shohamy, 2006) in which multiculturalism and multilingualism are not provided in educational space. In an informal discussion, the principal of a private Kathmandu school represents majority private school perspectives in stating that he was not aware that they have to teach local culture or the mother tongue. While agreeing that it is important to teach children about local cultures, he also argued that it is important to focus on teaching English in private schools to attract a large number of students. When asked whether or not an educator like him is responsible for promoting multiculturalism and multilingualism in education, he replied:

Yes, multiculturalism in an asset for us. We should promote it. ... But nobody can go beyond existing practices. You know... if we start teaching local cultures and languages students and parents do not take it positively. All big [renowned] private schools do not teach these subjects. If other schools teach local cultures and languages we will also ...teach. I think... government should be serious about this issue ${ }^{12}$.

Although some educators value multiculturalism, the ideology of "teaching English means providing quality education" adopted by private schools indicates that the English language has become a neoliberal commodity throughout the country. Also, since private schools are mostly based in urban cities, the students from these schools have already experienced modernity and embraced other transnational commodities such as foreign cinema, cable television, music, fashion, and languages. Ethnographic observations further suggest that youth who are products of English-medium private schools tend to lose their local languages and cultural identities while adopting Western influences like hip-hop and pop (Liechty, 2010).

Within rural poor areas, a combination of historical factors, neoliberalism, elitism, and lack of adequate information about multiculturalism/multilingualism has resulted in public-school parents' preference for English medium schools over local or indigenous language and cultural education ${ }^{13}$. Responding to the question about why indigenous communities are still reluctant to embrace MLE, a National MLE Directorate member contended that a long history of monocultural and monolingual ideology assumed that local indigenous languages and cultures are not worth learning. Moreover, lacking access to information about the significance of indigenous knowledge, many community members consider elite and educated language, culture, and knowledge as legitimate and desirable (Phyak, 2011). In addition to these locally-situated negative attitudes towards indigenous schooling, the chairperson of one school management committee from eastern Nepal contended that:

The State is not sincere to implement the policy [MLE]. It has not provided teachers for teaching in mother tongues. Schools have to manage resources themselves to appoint teachers from local communities [to teach in mother tongues]. Teachers are not provided training or instruction on how to develop 
teaching-learning materials. Parents and teachers are not well informed about the MLE policy ${ }^{14}$.

To address such criticisms from local/regional administrators and expand MLE throughout the country as an integral part of Nepalese education (MOE, 2010), the MOE is now working on its School Sector Reform Plan (2009-2015). The Plan asserts that MLE will be implemented in 7,500 schools by 2015 to redress learning challenges faced by children from minority language groups. Unfortunately, this has been implemented in less than two dozen schools to date.

Despite dispiriting observations and reports on the state of multicultural education in Nepal, recent (2006-2012) events have offered promise for the renewal of national and local community commitment to diversity and educational, social, and economic equity. Various ethnic organizations representing indigenous communities from state to village levels, under the umbrella of the Nepal Federation of Indigenous Nationalities (NEFIN), are proactively engaged in various movements for the promotion and protection of indigenous rights, knowledge, and languages. NEFIN has organized a series of activist activities such as awareness-raising campaigns at the local level. Ethnic organizations Yakthung Chumlung, Rai Yayokkha, and Newa Manka Khala, to name a few, are publishing magazines, newspapers, dictionaries, and books in their own languages and using them in the schools of their respective villages. For example, in collaboration with the Curriculum Development Center, Yakthung Chumlung (Phyak's peoples' organization) has already produced the textbook Ani Pan (Our Language) for the primary level and is now working on designing curriculum and textbooks for the higher secondary level. Ethnic organizations have also started broadcasting news and other awareness-raising cultural programs on local radio stations since mainstream media will not provide space for these purposes. Such ethnic organizations are not only resisting monoculturalism, but also persistently demanding identity-based federalism in which their languages, cultures, and values systems are provided respectable educational and sociopolitical space.

Most recently, in response to the imminent threat of returning to a monolingual/monocultural constitution, on May 10, 2012 the Nepal Federation of Indigenous Nationalities organized a mass rally in front of the Constituent Assembly Building in New Baneshwar, Kathmandu. Thousands of indigenous peoples from across the country gathered in the capital and warned the political leaders not to repeat a historical legacy of monocultural, monoreligious and monolingual policies. Youth activism in this movement is particularly strong. One indigenous activist leader and university student at Tribhuvan University, Lok (pseudonym), engages in multiple activities and movements related to ethnicity, language, culture, indigenous politics and identity, in addition to his studies. During the indigenous movement in May 2012, he addressed the masses of indigenous and other peoples more than six times in different places in Kathmandu. He appealed to all the people to resist monocultural hegemony to build a just and inclusive "New Nepal"15. Going back to the history of cultural and linguistic stratification, he contended that;

For 247 years [from 1768 - 2006] our languages, cultures and ethnicities were neglected.... Our identity was lost.... Our history was not written. We sacrificed our own knowledge for the sake of unity. We tolerated all kinds of discrimination 
and sense of humiliation and inferiority. And we are still tolerating [discrimination]... But the nation-state should not ignore our diverse linguistic, cultural and religious backgrounds [any more] ${ }^{16}$.

By unraveling injustice of the past, Lok educates people about how history has played a central role in marginalizing their languages, cultures, and identities. During a group discussion with the university students, referencing the school in his own indigenous community, Lok eloquently proclaimed that, although there are policies and constitutional provisions for multicultural and multilingual education, it is hard to put them into practice due to the lack of the nation-state's political will to do so. When Phyak visited Lok's community in the isolated rural eastern region of Nepal, he found that community members, teachers, and even resource persons were not familiar with the multilingual education policy and its relevance to the non-Nepali speaking minority children. During his stay in the village, Phyak engaged community members in discussion at different times and settings (individually and in groups), on various issues of politics and education. They told him that through these talks they began to realize the importance of the multilingual and multicultural education policy. They also became excited about sharing folktales ${ }^{17}$ that can be used to teach children in their own mother tongue. However, they also suggested that they need continued support - especially morale-building and technical assistance- to successfully promote local cultures and languages in the school.

Even though it is uncertain what political path the nation will take following the dissolution of the Constituent Assembly on 27 May, 2012, a significant indigenous ideological shift seems to be occurring from national and Western hegemony toward increasing awareness of native rights and a stronger commitment to resisting monocultural ideologies (Awasthi, 2004). It is also unclear at this early stage whether and how current emerging agency within indigenous communities may shape a discourse of inclusive democracy and education. Yet, the present ideological transformation of indigenous people is clearly a positive sign for building a more egalitarian and inclusive multicultural Nepalese society.

\section{Reimagining Globalization, Multiculturalism, and Education in Vietnam}

The extreme eagerness to promote market-oriented policies in the guise of globalization has tremendously impacted Vietnam's economy, education, politics, and foreign relations (McCargo, 2004). Contemporary scholars have worked to transform the traditional association of Vietnam from a war-based connotation to a country-based one (McCargo, 2004). Since 1986, leaders have further countered the country's "muddy days" of economic malaise, famine, poor infrastructures, insufficient skilled workers, foreign aid, illiteracy, and corruption with free market reforms known as Doi Moi (Renovation). Under a "socialist-oriented market economy," Doi Moi decentralizes state control by fostering local and private enterprise. In agriculture, Doi Moi reduces State land ownership and grants citizens long-term land ownership and the freedom to invest in market products. Doi Moi further offers rights to establish trade relations with foreign markets for both import and export purposes. The country also promotes trade liberation 
to create a global market economy by allowing competitive forces to come into Vietnam from abroad. In sum, Doi Moi replaces central planning with local, national and global markets (Kokko, 2004).

In the process of economic transformation, Vietnam has integrated ideologies that foster a less authoritarian and more multifaceted, multi-segmented, and multilayered (Dixon, 2004; McCargo, 2004) political agenda. For example, unlike the postwar period when media from Soviet countries predominantly traveled through national channels, the country's international integration invites diverse television networks such as Star Movies, CNN, BBC, and Fashion, as well as regional stations that include duplicated Western programs. Fast-food restaurants have mushroomed in big cities, subsequently promoting the perception of a fast-paced and modern lifestyle. The growing number of youth studying overseas further contributes to the influence of multiple sociocultural influences. In these and other ways, while many years ago the notion of success involved contributions for national reunification, patriotism, and the building of socialism, now urban youth view "success" as high incomes, educational attainment, and increased foreign relationships (Nguyen, 2004). School youth, influenced by media, technology, and foreign presence, are commonly known as the Blog, Facebook and Hip Hop Culture. Globalization and neoliberalism have clearly pluralized, hybridized, and commodified Vietnamese culture, especially within urban centers. Citizens, especially young indigenous people, are placed at the crossroads of negotiating local culture with other regional and Western cultures that intersect everyday life.

Transnationalism and neoliberalism have further impacted educational policies, but in ways profoundly different from economic reform. The Vietnamese government initiated a general curriculum and English language policy reform in 2000 and 2001 (Decrees No 40/2000/QH 10 and 14/2001/CT-TTg) that required Vietnam to "urgently develop and implement curriculum nationwide to meet the needs of the country's modern development." Yet while leadership has enacted decentralized economic policies, scholars such as Doan (2004) argue that the most problematic characteristic of educational reform is the remarkable centralism which controls all aspects of decision making, curriculum, quality, personnel, and finance, while adopting a one-size-fits-all curriculum (Doan, 2004). With centralism and the country's socioeconomic and educational shift towards English, various scholars (Lucius, 2009; Salemink, 2001; Truong, 2007) have indicated disappointing or conflicting educational outcomes while also noting the threat to minority cultures and languages. These factors are key to this engaged ethnographic account of how centralist educational polices impact teacher and minority-student schooling experiences in a remote mountainous region. The narrative shows how instructors and youth interpret their schooling experience and begin a transformative process towards more culturally and linguistically sensitive education.

Bui's ongoing work with youth and teachers is being conducted in a multiethnic high plateau and mountainous Northwest Vietnam province. This province is the home of 12 ethnic minority groups: Thai (54\%), Kinh (18\%), Hmong (12\%), Muong (8.4\%), Dao (2.5\%), and the remaining Kho Mu, XinhMun, Khang, La Ha, Lao, Tay, and Hoa. In possessing their own scripts and language, many minority groups have inherited legacies of historical literature, folk songs, customs, handicrafts, architecture, epics and 
legends (Dang, Chu, \& Luu, 2000; Salemink, 2001). Minority people also pride themselves on being stewards of local practices connected with agriculture, fishing, hand embroidery, healing, hunting, and animal-raising (Cam, 2007; Dang et al., 2000; Schliesinger, 1998). People further realize shared cultural knowledge through festivals such as rain praying, new year hair washing, ancestor thanksgiving, and agricultural exchange. However, minority peoples' rich linguistic and cultural heritages have not allowed them to achieve a favorable life; this province is the $5^{\text {th }}$ poorest province in Vietnam (VNHELP, 2012), with a large number of households living below the poverty line. The highest poverty levels (45.2\%) are those of the minority Tay, Thai, Muong, and Nung (Baulch, Nguyen, Phuong, \& Pham, 2010). These minority groups are largely dependent on subsistence agriculture for food and source of income. Moreover, as much as $40 \%$ of pre-schoolchildren are not able to speak Vietnamese, nor are they provided with the opportunity to use their native languages when they start primary school. In sum, these communities face education mandates that are largely unresponsive to their language, culture, and material conditions of poverty and poor health care (Schwind, 2010).

National Vietnamese policies suggest that centralized education and the dominant culture are active agents in claiming, marginalizing, and reproducing discourses that turn children from the uniqueness of their cultural and linguistic values towards the "legitimized" culture of the governing class. Condominas (2001) specifically argues that the nation cannot claim to respect their indigenous languages and cultures without respecting the people who produce them. Although Vietnam has received support from UNESCO (Salemink, 2001) and other foreign organizations to collaboratively participate in revitalizing tangible and intangible cultural and linguistic heritages, these efforts may focus on culture as artifact rather than the lived experiences and needs of these peoples.

Drawing on critical, collaborative and transformative approaches (Davis, 2009; Davis et. al., 2005; McCarty, 2011; Menken \& Garcia, 2010; Warren \& Mapp, 2005) and the centrality of history, culture and place (Luke, 2011), Bui engages Vietnamese youth and teachers in a process of unraveling how minority cultures and languages are positioned in educational policies. Together with community members, Bui explores how marginalization of minority ways of speaking and being may perpetuate social and educational inequalities. Accounting for teachers as policymakers and the epicenters of policy implementation (Menken \& Garcia, 2010; Willett \& Rosenberger, 2005), the following narrative also presents representative dialogue with educators that reveals possibilities for alternative ways in which to address economic, social, linguistic, and educational inequities.

Education policies that designate Vietnamese as the medium of instruction, require English courses, and establish standardized curricula serve as indicators of whose culture, whose language, and whose knowledge are legitimized. Dialogue with youth and teachers repeatedly confirm that the national curriculum fundamentally prohibits and/or marginalizes minority culture, traditions, and languages. A case in point is that teachers of the dominant Kinh (Vietnamese) group often struggle with teaching students from diverse backgrounds because of their limited multicultural and multilingual education training and potential sociocultural bias. Yet Bui's work in the community 
indicates a complex sense of teacher awareness, apathy, and empathy concerning national policies and local experiences. One teacher stated:

Because of the policy and the mismatch curriculum, teachers of English mostly perform their teaching because of their responsibility and not so much because of their caring and enthusiasm. As a result, students are provided with a skimpy insignificant and vague amount of knowledge. Although I am very sad but sometimes find myself being in this similar situation. After teaching, I feel like I want to stitch my lips together. I feel shameful and distressed ${ }^{18}$.

Bui's observations and critical reflection with educators and students suggest teacher frustration, negative judgments, and at times disrespectful and unprofessional behavior toward minority students in and out of school contexts. The standardized testing system further restricts curriculum content, reduces time on teaching, reproduces academic inequalities, and ignores language and cultures of diverse groups (Herman \& Golan, 1996; Luke, 2011). A student shared the following:

My teacher does not care much about students' multiple abilities. Once she requires the whole class to do a test, all students have to follow. There were no concerns about students' individual skills or abilities when testing. In fact, if teacher asks students to write a short composition (in English) as a test requirement, only some students can do, the rest of the class even do not understand what the test instruction requires them to do. We would like to have multiple ways to evaluate our learning abilities ${ }^{19}$.

This student states not only struggles with a third language, English (which is of questionable utility), but also the confusion and limitations of expression in standardized testing. This type of evaluation has eroded teachers' creativity and silenced student voices by not acknowledging multiple identities and indigenous knowledge within academic space.

Language policies focused on the teaching of Vietnamese and English clearly bring about tremendous difficulties for indigenous native language speakers. In a group discussion with four minority students engaged in a critique of the school language policy, one student observed that "learning English is difficult for me because English is different from my language. In addition, sentence order in my native language and Vietnamese is very different from English's syntax, so I feel confused when learning English $^{20}$." Another student added, "Because the three languages are very different, English is a strange subject to $\mathrm{me}^{21}$."

Students further critique schooling curriculum and teaching practices. One student acted as a policy arbitrator in this regard:

Teachers should not follow the textbook strictly. They need to invest time so that they can create more attractive activities based on the textbooks' topics. By doing that, they can create students' involvement in class and avoid stressful situations in dealing with students. By doing that, both teachers and students can help solve difficult problems for students ${ }^{22}$.

Students' critical reflection on policies revealed rejection of both standardized pedagogy and top-down management. They emphasize agency and ideological engagement in 
altering mechanical teaching and standard curriculum. Teachers began to hear these student voices and themselves feel empowered to incorporate culturally and linguistically appropriate assessment methods such as writing poems, news items, and postcards, rather than relying solely on standardized tests. Through these interactive dialogues, teachers seemed to be re-evaluating their teaching philosophies and pedagogies. The dialogues reflected anger and frustration over what they are told to replicate and also signaled growing lack of confidence in teaching that "is not genuine." As one teacher stated in a group discussion, "Sometimes we feel like we're just pretending to teach students because we are not a real owner of (knowledge about) many topics." Yet these collaborative reflections also reveal that they can teach differently when critically engaged in reinterpreting educational policies. Teachers indicate their increasing understanding of embedding students' cultures and traditions in teaching. More importantly, their characteristic prejudices against minority students are being transformed. A teacher said:

I am a Thai minority teacher myself but I do not know that it is encouraging and effective to incorporate my cultural traditions in teaching. Now I have more ideas to diversify my lessons. I feel wiser when talking to you (Bui) ${ }^{23}$.

Another teacher observed:

I realize that it is crucial to integrate minority cultural and linguistic aspects in teaching. I used to be very impatient and think negatively about minority students. I see you (Bui) being very patient listening to them. I should be different ${ }^{24}$.

Moreover, further dialogue with colleagues who teach Vietnamese literature revealed that they were beginning to incorporate critical topics such as "critiquing a national TV channel," "discussing unethical issues in your community," and "deconstructing the concept that minority culture is no longer pure" into class discussions and compositions.

Teachers' views increasingly affirm that an effective curriculum has to connect with students' sense of living space, tradition, and everyday practices to foster interest, effective learning, and pride in their being. According to the teachers, students are interested and remember lessons well when instruction is embedded into their agricultural practices. In one of the group discussions, a teacher reflected that:

Because the curriculum is divergent and too remote for minority and mountain students' conceptualizations, they understand very little. Because of too many remote lessons, students cannot imagine and they feel disinterested in learning. For example, when I teach students something about corn, sweet potatoes, and cassava, they are very interested. But now, many lessons about landscapes are very discrepant to what they know so they do not make sense to students. In grade 11, for example, vocabulary in one lesson is extremely overwhelming to students. Why are we forced to teach impractical lessons? Why educationists equate mountainous minority students with urban students? ${ }^{25}$

In sum, the Vietnamese case depicts the failure of the current centralist language policies that require English as a mandated subject for all students regardless of socioeconomic, linguistic, and cultural background. It reveals that policies which 
devalue the sense of belonging and cultural and linguistic heritages have directly resulted in confusion, resistance, conflict, and inequality for both teachers and students. This study reveals that language policies that ignore multiculturalism mean rejecting students' opportunities to develop multiple identities, abilities, and transformative agency. At the same time, this account emphasizes the potential of engaging students and teachers in negotiating, interrogating, and challenging unfavorable teaching and learning situations, policy mismatches, and marginalizing discourses. Moreover, engagement with youth indicates that, as they become critical about social and educational inequalities, they gradually spread this critical stance to their families and others in the community. Teachers are also beginning to engage in critical dialogue with students, parents, community members, and local indigenous leaders about ways in which to ameliorate poverty, unequal land ownership, excessive use of agricultural pesticides, hygiene challenges, natural resource exploitation, and sustainable economic development. Based on this Freirean model that is locally shaped and globally aware, it is hoped that ongoing critical situated research will expand and organize relationships with others in Vietnam and elsewhere to promote diversity and embrace movement toward greater equality.

\section{Multicultural Education as Community Engagement}

The transnational studies described here take a critical ethnographic approach to diversity that is multidisciplinary, multi-method, and focused on community engagement at multiple intersecting levels. Thus, diversity is viewed as engaging (a) critical awareness of transnationalism, neoliberalism, and education; (b) communities through collaborative research and mentorship; and (c) schools, policies, and plans towards transformative educational practices. In the following, we explore the implications of community engagement at these intersecting levels through comparative analyses (McCarty, Collins, \& Hopson, 2011) of the Nepal and Vietnam studies.

\section{Transnationalism, Neoliberalism, and Education}

The Nepal critical ethnography reveals that, although the Interim Constitution2007 multilingual/ multicultural policies offered potential for more equitable education, the neoliberal-inspired English-only medium of instruction has led to de facto monolingual education in private schools and little or no education in public schools. Nepal's transformative struggles currently look toward engaged resistance to cultural hegemony together with renewed efforts in multilingual/multicultural and equity education. Vietnamese education for minority populations has been mandated by a centralist educational policy that largely ignores language and cultural diversity while adopting the neoliberal doctrine of English as a privileged commodity. These South Asia and Southeast Asia cases present convincing evidence that English and Western cultural commodification and distribution threaten indigenous/minority languages, identities, and knowledge. More immediately devastating is the economic threat posed 
by inadequate education resulting from monolingual English or Nepali and Vietnamese medium schools (with English courses) that further disadvantage the disadvantaged (Luke, 2010). More comparative studies are needed to register the scope and depth of transnational multicultural and economic threat from neoliberal English commodification.

\section{Engaging Communities through Collaborative Research and Mentorship}

We concur with indigenous activist scholars (e.g., Maaka et al., 2011; Smith, 2012) that researchers and educational planners who are from marginalized communities and take a critical perspective on external and internal sociopolitical conditions are most likely to help bring about equitable transformative action. Deep connection to communities additionally provides local legitimacy and reflects personal commitment to engaging communities in research, reflection, and advocacy. We also argue for community engagement that includes far-ranging and in-depth analysis and dialogue with individuals, institutions, and policies. Phyak's dialogic work in Nepal has involved engaging communities of government officials and bureaucrats; official and implicit policies; profit and non-profit organizations' programs for minorities/the disenfranchised; mid-level educational bureaucrats who accommodate or promote change; teachers' and administrators' knowledge, beliefs, and access to information; activist/advocacy group movement toward equity transformation; and parents, elders, students/youth as ideological consumers, advocates, and activists. In effect, we argue that engagement involves the range of salient participants and issues that impact social equity and human welfare in any given situation.

Mentorship, especially among youth, is also crucial to fostering multicultural identities and agency. Researchers can and do effectively model critical dialogue through their own engagement with communities. Yet comprehensive mentorship within institutions such as universities, NGOs, and community organizations can provide substantive and long-term assistance to scholars, leaders, and youth from marginalized/disenfranchised communities towards transformative engagement (Smith, 2012). This process can cover the range of mentoring needs as determined through ongoing local or situated dialogue. For example, engaged multicultural education at the university level may include analyses of ideological and theoretical perspectives that cross disciplines and specifically relate to local/situated issues. Through institutions of higher learning and/or community outreach programs, youth can explore social welfare and justice concerns that include but go beyond schooling towards community change. Also needed are knowledge and models of community activism, including politics and practices; decolonizing research methodologies as described here (see also Smith, 2012); and knowledge, skills, and practice in dissemination of information through local media and transnational forums, such as international journals and the internet.

\section{Challenging Policies and Engaging Educational Planning}


History, place, culture (Luke, 2011) and political circumstances (McCarty, Collins, \& Hopson, 2011) often prevent overt activism, advocacy, and mentorship at different times in various locations. While working under quite different historical, cultural, and political circumstances, both Bui and Phyak portray the centrally important need and potential for positive transformation in working on the ground with communities of teachers, children, youth, and parents. Bui focuses her engaged ethnographic work with students and teachers on opening spaces (Bhabha, 1994) for realizing minority language and education rights under restrictive centralist education policies. She engages indigenous students and teachers in Freirean forms of dialogue adapted to local cultural perspectives for addressing not only issues directly associated with education, but also those challenges faced by minority cultures across a broad spectrum of equity, health, and human welfare issues (see also Hymes, 1996; Van der Aa \& Blommaert, 2011). Phyak describes his efforts in a remote village towards political conscious-raising and practical community/language-based school materials development. This engaged community work may also provide mentoring opportunities for future leaders and/or teacher educators as they participate in engaging teachers, parents, and students in multicultural education work within community schools.

While government policies often situate indigenous and other marginalized peoples as passive recipients of oppressive or ameliorative educational actions (Luke, 2011), we have argued here for multicultural/multilingual policy and planning as engagement and action that is globally informed and locally enacted. We intend that the theories and models presented not only promote transnational and national understandings of multicultural education, but also and primarily support policy activism, community engagement and policy/practice transformation towards inclusion, equity, and human welfare.

\section{Notes}

1. The Census Report-2001 shows 100 ethnic/caste groups and 92 languages in Nepal. It reveals that Hill Bahuns and Chetris occupy 12.74 and 18.15 percent of total population. Nepali as a mother tongue is spoken by $48.6 \%$ and the remaining populations speak minority languages such as Maithili, Rai, Limbu, Newari, Tamang, Magar, and Gurung. Due to the imposition of Hindu, almost $80 \%$ of total population now claims this religion.

2. The Panchayat adopted the Nepal National Education Planning Commission's (NNEPC) recommendation that "No other languages [than Nepali] should be taught, even optionally in primary school, because [only] a few children will need them and they would hinder the use of Nepali ... and those who wish and need additional languages can learn them in the sixth grade." (NNEPC, 1956, p. 95)

3. For example, Newars from the Kathmandu valley formed Nepal Bhasa Manka Khala (1979) to promote their language, script and culture. 
4. More information about Nepal Federations of Indigenous Nationalities is available at http://www.nefin.org.np/list/About-Us/4/0/0

5. Although this paper focuses on the data collected during May-August, 2012, Phyak brings his over six years of ethnographic work with indigenous communities and his own Limbu indigenous identity to bear on the issues of language, culture, and identity in Nepal discussed here.

6. Most of the MOE official documents, including the National Curriculum Framework, are written in English.

7. हामीले यसको लागि धैरै बर्ष माग गरेका थियौ। हाम्रो बच्चाहरुलाई नेपालीमा मात्र पढाइन्थ्यो। उनीहरुले नेपालीमा पढाएको बझ्दैनथे। अहिलेको सरकारी निती राम्रो छ। यसले गर्दा हाम्रा बच्चाहरुले सजिलै सगं सिक्न सक्ने भएका छन। अहिले कुनै हिचकिचावट आफ्ना साथीहरु र शिक्षकहरु सगं कुराकानी गर्न सक्छन्। स्थानीय भाषा र संस्कृतिको प्रयोगले गर्दा स्कुलमा बाल मैत्री वातावरण बनेको छ।

8. स्थानीय इतिहास, संस्कृति, जडीबुटी, कथा र कला जान्ने पाका आदिबाशीहरुले आफ्नो अनुभव भन्नु हुन्छ। यस्ता अनुभवहरुलाई रेकर्ड गरी पाठ्यपुस्तक निर्माण गर्न प्रयोग गरिन्छ। समुदायका मानिसहरुलाई पाठ्यपुस्तकको बिषय बस्तु छान्न सक्रिय रुपमा सहभागी गराइन्छ।

9. बच्चाहरुले आफ्नो घरमा बोलिने भाषाबाट राम्रो सिक्छन। अहिलेको बहुभाषिक शिक्षाले नितिमा स्थानीय संस्कृतीहरु पढाएर बहुसंस्कृतिक वातावरण बनेको छ।

10. Previous studies (e.g., Skutnabb-Kangas \& Mohanty, 2009) have suggested that the lack of well-informed resources, teachers, and parents can significantly impact implementation of MLE.

11. "Local Subject" is the term used in the 2007 National Curriculum Framework for School Education. The National Curriculum Framework is written in English. This refers to teaching of local cultures, histories, stories, and life styles.

12. बहुसंस्कृति हाम्रो सम्पति हो। हामीले यसलाई सम्बर्दन गर्नु पर्छ। तर कोही पनि प्रचलित अभ्यासहरु भन्दा माथि जान सक्दैन। तपाईलाई थाहै यदि हामील स्थानीय भाषा र संस्कृतीहरु पढाउन थाल्यौ भने अभिभावक र बच्चाहरुले सकरात्मकरुपमा लिनु हुन्न। सबै ठुला प्राइभेट स्कुलहरुले यी बिषयहरु पढाउनु हुन्न। यदि अरु स्कुलहरुले स्थानीय भाषा र संस्कृतीहरु पढाउनु हुन्छ भने हामी पनि पढाउछौ। मेरो बिचारमा यो बिषयमा सरकार गम्भीर हुनु पई।

13. Based on field observation of two public schools (from May-August 2012), Phyak found that there is negligible use of English while teaching subjects like social studies, mathematics, and population and environment studies at the primary level. Not only is language expertise absent, but the move to neglect emergent 
multilingualism in these rural schools further hampers students' achievement and leads to indigenous language loss.

14. बहुभाषिक शिक्षा निती लागु गर्न राज्यनै ईमान्दार छैन। मातृभाषामा पढाउने शिक्षक उपलब्ध गराइएको छैन। स्कुलहरु आंफैले स्रोत जुटाएर मातृभाषा शिक्षकको व्यवस्था गर्नु पर्छ। मातृभाषा शिक्षकहरुलाइ शैक्षिक सामाग्रीहरु कसरी बनाउने भन्ने तालिम दिइएको छैन। बहुभाषिक शिक्षा नितीको बारेमा अबिभावक र शिक्षकहरुलाइ राम्रो जानकारी गराइएको छैन।

15. The term "New Nepal" has become a key rhetoric in Nepalese politics to describe the post-2006 era (i.e., post-Monarchy overthrow). It indicates that Nepal has entered into the new era as it ended its 247-year-old hereditary monarchy.

16. २४७ बर्ष सम्म हाम्रो भाषा, संस्कृति र जातियताहरुलाइ अपहेलना गरिएको थियो। हाम्रो पहिचान हराएको थियो ... हाम्रो इतिहास लेखिएको थिएन। एकताको लागि हामीले आफ्नो ज्ञानहरु पनि बिर्सिदियऊ। हामीले सबै किसिमका बिभेद, अन्याय, र अपहेलनाहरू सहयौ। हामीले अझै सम्म पनि सहीरहेका छौ ... तर राज्यले हाम्रो भाषिक, सांस्कृतिक र धार्मिक विबिधतालाई बिर्सनु हुन्न।

17. Phyak and the community members are working on compiling and publishing those folktales.

18. Do chính sách và chương trình học không phù hợp, giáo viên tiếng Anh phần lớn dạy vì trách nhiệm và cũng không nhiều do quan tâm hay đồng cảm với học sinh. Do đó, học sinh được cung cấp với lượng kiến thức ít ỏi, không có ý nghĩa, và lơ mơ. Mặc dù nhiều khi em cũng cảm thấy buồn khi rơi vào tình trạng này. Sau khi dạy xong, em cảm thấy như em muốn khâu miệng mình lại. Em cảm thấy xấu hổ và căng thẳng.

19. Cô giáo không quan tâm nhiều đến các khả năng khác nhau của học sinh. Một khi cô yêu cầu cả lớp làm bài kiểm tra, tất cả đều phải theo. Chẳng có quan tâm về các khả năng khác nhau của học sinh khi làm bài kiểm tra gì cả. Thực tế là môt khi cô giáo yêu cầu học sinh viết một bài luận ngắn là bài kiểm tra, chỉ một số học sinh có thể làm được, phần còn lại của lớp thậm chí chưa hiểu bài kiểm tra yêu cầu gì. Chúng em muốn có nhiều cách kiểm tra trình độ của bọn em.

20. Học tiếng Anh thật là khó đối với em vì tiếng Anh khác với tiếng của em. Thêm vào đó trật tự câu trong tiếng mẹ đẻ của em và tiếng Việt rất khác tiếng Anh nên em cảm thấy bối rố khi học tiếng Anh.

21. Bởi vì ba ngôn ngữ rất khác nhau, tiếng Anh là môn học lạ lùng đối với em.

22. Cô giáo không nên chỉ theo hết sách giáo khoa mà cần đầu tư nhiều thời gian để đưa ra những hoạt động hấp dẫn dựa trên nền các chủ điểm của sách giáo khoa. Nếu làm như vậy, thầy, cô sẽ thu hút được sự tham gia của học sinh và tránh được những tình huống căng thẳng khi phải đối đầu với hợc sinh. Nểu làm như vậy, cả giáo viên và học sinh cùng nhau giải quyết những vấn đề khó khăn cho học sinh. 
23. Em là giáo viên người Thái nhưng mà em không biết rằng việc đưa văn hóa truyền thống dân tộc mình vào giảng dậy sẽ hiệu quả và nên được cổ vũ. Bây giờ em có nhiều ý tưởng hơn để đa dạng hóa bài dậy của em. Em cảm thấy khôn hơn khi nói chuyện với chị.

24. Em nhận thấy rằng việc kết hợp văn hóa và ngôn ngữ dân tộc vào giảng dậy rất quan trọng. Em thường nghĩ tiêu cực và rất thiếu kiên nhẫn với học sinh dân tộc. Em nhìn thấy chị rất kiên nhẫn khi nói chuyện với chúng. Em nên phải khác.

25. Bởi vì chương trình học khác và quá xa xôi với cách suy nghĩ của học sinh dân tộc và miền núi, các em hiểu rất ít. Bởi vì có quá nhiều bài học xa vời, học sinh không thể tưởng tượng nổi và các em cảm thấy chán học. Ví dụ khi chị dạy học sinh những thứ như là ngô, khoai lang, hay sắn, các em rất thích học. Nhưng bây giờ nhiều bài học như là danh lam thắng cảnh rất xa xôi với những gì các em biết nên các em không hiểu. Ở lớp 11, chẳng hạn, từ vựng trong một bài học cực kì nhiều, choáng ngợp học sinh. Tại sao bọn chị lại bị bắt buộc dạy những bài dạy không thực tế thế này? Tại sao những nhà giáo dục lại đánh đồng học sinh dân tộc với học sinh ở thành thị?

\section{References}

Allen, N. J. (1997). Hinduization: The experience of the ThulungRai. In D. N. Gellner, J. Pfaff-Czarnecka, \& J. Whelpton (Eds.), Nationalism and ethnicity in Hindu Kingdon: The politics of culture in contemporary Nepal (pp. 303-324). Amsterdam, The Netherlands: Harwood Academic Publishers.

Anthias, F. (2001). New hybridities, old concepts: The limits of 'culture'. Ethnic and Racial Studies, 24, 619-641.

Appadurai, A. (1996). Modernity at large: Cultural dimensions of globalization. Minnesota, MN: University of Minnesota Press.

Appadurai, A. (2001). Deep democracy: Urban governmentality and the horizon of politics. Environment and Urbanization, 13(2), 23-43.

Awasthi, L. D. (2004). Exploring monolingual school practices in multilingual Nepal (Unpublished doctoral dissertation). Danish University of Education, Copenhagen, Denmark.

Baulch, B., Nguyen, H., Phuong, P., Pham, H. (2010). Ethnic minority poverty in Vietnam. Retrieved from http://www.isn.ethz.ch/isn/Digital-Library/Publications/ Detail/?ots591=cab359a3-9328-19cc-a1d2-8023e646b22c\&lng=en\&id=127428

Bhabha, H. K. (1983). The other question. Screen, 24(6), 18-36.

Bhabha, H. K. (1994). The location of culture. London, UK: Routledge.

Block, D. (2006). Multilingual identity in global city: London stories. London, UK: Palgrave Macmillan.

Bourdieu, P. (1991). Language and symbolic power. Cambridge, UK: Polity Press. 
Bourdieu, P. (1998). Practical reason: On the theory of action. Stanford, CA: Stanford University Press.

Beukes, A-M. (2009). Language policy incongruity and African languages in postapartheid South Africa. Language Matters: Studies in the Languages of Africa, 40(1), 35-55.

Cam, T. (2007). The Thai ethnic community in Vietnam. Hanoi, Vietnam: The Gioi Publisher.

Carney, S. (2009). Negotiating policy in an age of globalization: Exploring educational "policyscapes" in Denmark, Nepal, and China. Comparative Education Review, 53, 63-88.

Cochran-Smith, M. (2005). The politics of teacher education and the curse of complexity. Journal of Teacher Education, 56, 181-185.

Condominas, G. (2001). Introduction. In O. Salemink (Ed.), Vietnam's cultural diversity: Approaches to preservation (pp. 15-32). Paris, France: UNESCO.

Curriculum Development Center (2008). Curriculum for primary level. Bhaktapur, Nepal: CDC.

Dang, N. V., Chu, T. S., \& Luu, H. (2000). Ethnic minority in Vietnam. Hanoi, Vietnam: The Gioi Publishers.

Dang, N. V (2001).Preservation and development of the cultural heritage. In $\mathrm{O}$. Salemink (Ed.), Vietnam's cultural diversity: Approaches to preservation (pp. 1633). Paris, France: UNESCO.

Davis, K., Cho, H., Ishida, M., Soria, J., \& Bazzi, S. (2005). "It's Our Kuleana": A critical participatory approach to language minority education. In L. Pease-Alvarez \& S. R. Schecter (Eds.), Learning, teaching, and community (pp. 3-25). Mahway, NJ: Lawrence Erlbaum Associates.

Davis, K. (2009). Agentive youth research: Towards individual, collective, and policy transformations. In T. G. Wiley., J. S. Lee., \& R. Rumberger (Eds.), The education of language immigrants in the USA (pp. 200-239). London, UK: Multilingual Matters.

Decree No 40/2000/QH10 (2000). The congress' decree on general education curriculum reform. Retrieved from http://www.moet.gov.vn/?page=6.21\&script= congvan\&namxly=-1

Decree No 14/2001/CT-TTg. (2001). The prime minister's directive on general education reform. Retrieved from http://www.moet.gov.vn/?page=6.21\&script=congvan\& namxly=-1

Dixon, C. (2004). State, party and political change in Vietnam. In D. McCargo (Ed.), Rethinking Vietnam (pp. 143-152). London, UK: Routledge.

Doan, D. H. (2004). Centralism - The dilemma of educational reforms in Vietnam. In D. McCargo (Ed.), Rethinking Vietnam (pp. 143-152). London, UK: Routledge. 
Eagle, S. (2008). The language situation in Nepal: A 2007 update. In R. B. Baldauf \& R. B. Kaplan (Eds.). Language planning in Asia. Volume 1: Japan, Nepal, Taiwan and Chinese Characters (pp.170-225). Sydney, Australia: Multilingual Matters.

Freire, P. (1970). Pedagogy of the oppressed. New York, NY: Continuum.

Gegeo, D., \& Watson-Gegeo, K. (2002).Whose knowledge? Epistemological collisions in Solomon Islands community development. The Contemporary Pacific, 14(2), 377-409.

Giri, R. A. (2010). Cultural anarchism: The consequences of privileging languages in Nepal. Journal of Multilingual and Multicultural Development, 31(1), 87-100.

Graff, H. A. (1979) The literacy myth. New York, NY: Academic Press.

Gurung, H. (2006). From exclusion to inclusion: Socio-political agenda for Nepal. Lalitpur, Nepal: Social Inclusion Research Fund, SNV, Nepal.

Hangen, S. I. (2010). The rise of ethnic politics in Nepal: Democracy in the margins. New York, NY: Routledge.

Herman, J., \& Golan, S. (1991). Effects of standardized testing on teachers and learning-Another look. Los Angeles, CA: National Center for Research on Evaluation, Standards, and Student Testing (CRESST), UCLA Graduate School of Education. Retrieved from http://www.google.com/search?q=impact of testing onteaching\&ie=utf-8\&oe=utf-8\&aq=t\&rls=org.mozilla:en-US:official\&client=firefoxa

Holland, D., \& Lachicotte, Jr., W. (2007). Vygotsky, Mead, and the new sociocultural studies of identity. In H. Daniels, M. Cole, \& J. V. Wertsch (Eds.), The Cambridge companion to Vygotsky (pp. 101-135). Cambridge, UK: Cambridge University Press.

Hough, D., Thapa-Magar, R. B., \& Yonjan-Tamang, A. (2009). Privileging indigenous knowledges: Empowering MLE in Nepal. In T. Skutnabb-Kangas, R. Phillipson, A. Mohanty, \& M. Panda (Eds.), Social justice through multilingual education (pp.159-176). Bristol, UK: Multilingual Matters.

Hymes, D. (1996). Ethnography, linguistics, narrative inequality: Toward an understanding of voice. New York, NY: Taylor and Francis.

Khanal, P. (2010). School decentralization in Nepal: A disjuncture between macro-level advocacy and micro-level reality? Educational Research for Policy and Practice, 9(3), 145-158.

Kokko, A. (2004). Growth and reform since the Eight Party Congress. In D. McCargo (Ed.), Rethinking Vietnam (pp. 143-152). London, UK: Routledge.

Lather, P. (2004). This is your father's paradigm: Government intrusion and the case of qualitative research in education. Qualitative Inquiry, 10(1), 15-34.

Liechty, M. (2003). Suitably modern: Making middle-class culture in a new consumer society. Princeton, NJ: Princeton University Press. 
Liechty, M. (2010). Out here in Kathmandu: Modernity on the global periphery. Kathmandu, Nepal: Martin Chautari Press.

Lo Bianco, J. (2010). Language policy and planning. In N. Hornberger \& S. McKay (Eds.), Sociolinguistics and language education (pp. 143-174). Bristol, UK: Multilingual Matters.

Lucius, C. (2009). Vietnam's political process: How education shapes political decisionmaking. New York, NY: Routledge.

Luke, A. (2008). Another ethnic autobiography? Childhood and the cultural economy of looking. In R. Hammer \& D. Kellner (Eds.), Critical cultural studies reader. New York, NY: Peter Lang.

Luke, A. (2011). Generalizing across borders policy and the limits of educational science. Educational Researcher, 40(8), 367-377.

Maaka, M. J., Wong, K. L., \& Oliveira, K. K. R. (2011). When the children of their fathers push back!: Self-determination and the politics of indigenous research. In Davis, K. (Ed.). Critical qualitative research in second language studies: Agency and advocacy. Greenwich, CN: Information Age Publishing.

Maaka, R., \& Andersen, C. (2006). The indigenous experience: Global perspectives. Toronto, Canada: Canadian Scholars' Press.

McCargo, D. (2004). Introduction. In D. McCargo (Ed.), Rethinking Vietnam (pp. 1-12). London, UK: Routledge.

McCarty, T. L. (2011). Introducing ethnography and language policy. In T. McCarty (Ed.), Ethnography and language policy (pp. 1-28). New York, NY: Routledge.

McCarty, T. L., Collins, J., \& Hopson, R. K. (2011). Dell Hymes and the new language policy studies: Update from an underdeveloped country. Anthropology \& Education Quarterly, 42(4), 335-363,

Menken, K., \& Garcia, O. (2010). Negotiating language policies in schools: Educators as policymakers. New York, NY: Routledge.

Ministry of Education (2010). The multilingual education program implementation multilingual education. Kathmandu, Nepal: Government of Nepal.

National Curriculum for School Education in Nepal. (2005). Bhaktapur, Nepal: Ministry of Education, Curriculum Development Center.

Nguyen, A. P. (2004). Pursuing success in present-day Vietnam: Young graduates in Hanoi. In D. McCargo (Ed.), Rethinking Vietnam (pp. 154-165). London, UK: Routledge.

Nurmela, I., Awasthi, L. D., \& Skutnabb-Kangas, T. (2011). Enhancing quality education for all in Nepal through indigenised MLE: The challenge to teach in over a hundred languages. In Skutnabb-Kangas, T. \& Heugh, K. (eds.), Multilingual education and sustainable diversity work: From periphery to center (pp.151-177). New York, NY: Routledge. 
Orfield, G., Losen, D., Wald, J., \& Swanson, C. (2004). Losing our future: How minority youth are being left behind by the graduation rate crisis. Cambridge, MA: The Civil Rights Project at Harvard University.

Pfaff-Czarnecka, J. (1997). Vestiges and visions: Cultural change in the process of nation-building in Nepal. In D. N. Gellner, J. Pfaff-Czarnecka, \& J. Whelpton (eds.), Nationalism and ethnicity in Hindu Kingdon: The politics of culture in contemporary Nepal (pp. 419-470). Amsterdam, The Netherlands: Harwood Academic Publishers.

Phyak, P. (2011). Beyond the façade of language planning for Nepalese primary education: Monolingual hangover, elitism and displacement of local languages? Current Issues in Language Planning, 12(2), 265-287.

Romero-Little, M. E. (2010). How should young indigenous children be prepared forlearning?: A vision of early childhood education for indigenous children. Journal of American Indian Education, 49(1\&2), 7-27.

Salemink, O. (2001). Who decides who preserves what? Cultural preservation and cultural representation. In O. Salemink (Ed.), Vietnam's cultural diversity: Approaches to preservation (pp. 200-205). Paris, France: UNESCO.

Schliesinger, J. (1998). Hill tribes of Vietnam (vol. 2): Profiles of existing hill tribe groups. Bangkok, Thailand: White Lotus Press.

School Sector Reform Plan (2009-2015). Kathmandu, Nepal: Ministry of Education.

Schwind, B. (2010). Barriers to health care for the poor and ethnic minorities in Northwest Vietnam. Retrieved from http://www.socialsecurityextension.org /gimi/gess/RessShowRessource.do?ressourceld=16732

Skutnabb-Kangas, T., \& Mohanty, A. (2009). Policy and strategy for MLE in Nepal. Sanothimi, Bhaktapur, Nepal: Department of Education.

Smith, L. T. (2012). Decolonizing methodologies: Research and indigenous peoples $\left(2^{\text {nd }}\right.$ ed.). London, UK: Zed Books.

Shohamy, E. (2006). Language policy: Hidden agendas and new approaches. New York, NY: Routledge.

Tsui, A., \& Tollefson, J. W. (Eds.). (2007). Language policy, culture, and identity in Asian contexts. Mahway, NJ: Lawrence Erlbaum Associates.

Truong, H. C. (2007). "They think we don't value schooling": Paradoxes of education in the multi- ethnic Central Highlands of Vietnam. In J. D. London (Ed.), Education in Vietnam (pp. 171- 211). Singapore: Institute of Southeast Asian Studies.

Van der Aa, J., \& Blommaert, J. (2011). Ethnographic monitoring: Hymes's unfinished business in educational research. Anthropology \& Education Quarterly, 42(4), 319-334.

VNHELP (2012). Project update: Getting to know Son La and the benefits of education. Retrieved from http://vnhelp.wordpress.com/2012/05/16/project-update-gettingto-know-son-la-and-the-benefits-of-education/ 
Warren, M. R., \& Mapp, K. L. (2011). A match on dry grass: Community organizing for school reform. Oxford, UK: Oxford University Press.

Wiley, T., \& Wright, W. (2004). Against the undertow: Language-minority education policy and politics in the "age of accountability." Educational Policy, 18(1), 142168.

Willett, J., \& Rosenberger, C. (2005). Critical dialogue: Transforming the discourses of educational reform. In L. Pease-Alvarez \& S. R. Schecter (Eds.), Learning, teaching, and community: Contributions of situated and participatory approaches to educational innovation (pp. 191- 213), Mahwah, NJ: Lawrence Erlbaum Associates.

Whelpton, J. (2005). A history of Nepal. Cambridge, UK: Cambridge University Press.

Widin, J. (2010). Illegitimate practices: Global English language education. Bristol, UK: Multilingual Matters.

Zingerli, C. (2004). Politics in mountain communes: Exploring Vietnamese grassroots democracy. In D. McCargo (Ed.), Rethinking Vietnam (pp. 53-66). London, UK: Routledge. 